\title{
THE EFFICIENCY OF THE UKRAINIAN INSURANCE MARKET
}

\section{Yekhalova Anna ${ }^{1}$}

DOI: https://doi.org/10.30525/978-9934-571-89-3_126

One of the driving forces in the development of the national economy is the timely and effective financial support of the real sector of the economy from the side of the insurance market in the case of an insurance event's approach. The analysis of recent researches and publications has shown that the problem of increasing of the efficiency of the insurance market functioning was investigated by many scientists, in particular, Kolomina Y.V., Chornoguzova T.N., Maruzhenko D.S., Oparina V.M., Gamankova O.O., Shirinyan L., Nechiporuk L.V., Kyrylo V. [1], Ermolenko G.G., Javorsjka T.V. [2], and this direction of investigation of the insurance market needs further development. One of the most important problem due to the process of evaluation of the efficiency of any economy branch is the definition of indicators of its efficiency and their consolidation into a system. It should be noted that the efficiency indicators of the national insurance market are fundamentally different from the world's ones due to the peculiarities of the transformational processes in the national economy.

The purpose of the article is to evaluate the effectiveness of the functioning of the national insurance market through the system of consolidated indicators considering to the inversion way of national economy development. At the present stage of development of the national insurance market along with the classic meaning of insurance, which lays in ensuring the economic security of the state and sustained production cycle, new challenges arise. They are facilitated by the emergence of new risks, increasing the frequency of insurance events, saving budget funds at the expense of compensation to the insured persons. According to this situation, an increase of the demand for insurance security, which leads to an intensification of the offer of insurance services on the market, is expected. At the same time, the spread of insurance involves an increase in the number of insurers, a rise of insurance rates, which requires the renovation of the structure and infrastructure of the market, as well as improving the mechanism of state regulation of the insurance market. But the increase of the demand for insurance services doesn't happened, while the burden on the state budget remains too heavy, the level of capitalization of the insurance market decreases, insurers generate profits mainly due to 2-3 types of compulsory insurance, the professional level and the quality of insurance protection remains low.

The paradoxes of low rates of insurance on condition of the unsaturated market, the low demand for insurance services considering high need for insurance protection, the weak offer of insurance services considering the high market capacity, disproportion of market differentiation to types of insurance services,

${ }^{1}$ Taurida National V.I. Vernadsky University, Ukraine 
ineffective geographical diversification, low insurance culture on condition of low awareness of insured persons are concerned with special circumstances of the national economy develop processes. It should be noted that in order to understand the causes of these paradoxes, we must emphasise the peculiarities of the transformational processes in the national economy: transition from the planned economy to the market one led to the indirect way of the financial and, in particular, of the insurance market development [1, p. 212]. Thus, the national insurance market inversely changed from the state form of ownership of insurance assets to other forms of ownership, based primarily on share capital, from the state monopoly in insurance to a competitive market, from state insurance rates to free pricing [2, p. 117].

The inversion way of the development of insurance in Ukraine is caused mostly by inflationary surges and spontaneous privatization of property, which provoked the accumulation of funds in the insurance sector through redistributive financial processes among market participants and the insurers' avoidance of payments in 1990s. In addition, the mass devastation of industrial objects on condition of the backdrop of lack of investment, increasing value of the raw materials and the lack of innovation, as well as changing of social priorities, that led to replace the classical meaning of insurance, as a mechanism of compensation damages, to the tool of minimizing tax payments and legitimizing doubtful financial flows. On the early stages of the formation of the national insurance market, its structure was characterized by a large number of insurers and low quality of insurance services provided due to low barriers to entry, easy registration procedure, state interest in increasing the size of the insurance market and non strict requirements for the insurers' financial solvency. The current trend is to reduce the number of insurance companies on the national insurance market, the reasons of which are: strengthening the state control of insurers; forcing insurers out of the market due to lack of funds and low profit; withdrawal of a license; activation of merger and acquisition processes, etc.

There are different approaches to the calculation of indicators of concentration and competitiveness of market environments. In the insurance the HerfindahlHirschman Index (HHI) is often used: according to the results of 2017 in life insurance segment, it amounted to 1417.52 (in 2016 - 1079.59), it was 305.27 for risky insurance (in 2016-280.74); on the whole insurance market it amounted to 272,07 (in 2016 - 245,09) [3]. In the risk segment of the market, competition is high, in the life insurance segment, competition is much weaker and stands at a satisfactory level, when the growth of HHI in the dynamics is indicating an increase in the level of monopolization on the market [3]. This indicates the overburdance of insurers and ineffectiveness of their work in the risk segment of the insurance market [2, p. 121]. An evaluation of the total effectiveness of the insurance market could be conducted on the basis of such consolidated indicators as: the penetration of the insurance market in the GDP, the market density, and the level of gross payments idemnity [3]. The penetration of the insurance market in the GDP is a share of aggregate insurance premiums in the GDP (Table 1). 
Table 1

The main indicators of the insurance market effectiveness in Ukraine

\begin{tabular}{|c|c|c|c|c|c|c|c|}
\hline 2010 & 2011 & 2012 & 2013 & 2014 & 2015 & 2016 & 2017 \\
\hline \multicolumn{7}{|c|}{ The penetration of the insurance market in the GDP, \% } \\
\hline 2,13 & 1,73 & 1,52 & 1,96 & 1,69 & 1,53 & 1,71 & 1,79 \\
\hline \multicolumn{7}{|c|}{ The market density, \$ } \\
\hline The market density, $€$ & \multicolumn{7}{|c|}{ The level of gross payments indemnity, \% } \\
\hline 45,01 & 45,7 & 45,02 & 79,02 & 37,03 & 29,9 & 30,2 & 36,32 \\
\hline \multicolumn{7}{|c|}{ The } \\
\hline 26,45 & 21,43 & 23,95 & 16,23 & 18,91 & 21,5 & 25,1 & 24,3 \\
\hline
\end{tabular}

Source: compiled by author based on [3]

The penetration of the insurance market in the GDP is significantly lower than the critical value, which reflects the required safe level and equals $8 \%$ [3]. The density of the national insurance market expresses the cost of insurance per head in monetary terms and is calculated as the ratio of the number of insurers to the population. The index of the density of the insurance market in Ukraine is less than 40 US dollars and significantly less than the critical level, which is 140 US dollars per head [3], mostly due to the low income and low popularity of insurance among the population (Table 1).

Despite the gradual economic growth and the adoptable level of consumer inflation, the volatility of the national currency, the decline in consumer demand and in real income of the population still have prolonged impact on the insurance market and restrain the growth of the insurance efficiency, and as a result inhibit its exit from the inversial spiral. The main objective of the insurance market functioning is the accumulation and redistribution of funds among market players in order to compensate for losses in the case of an insured event. Mathematically, an achievement of this objective can be evaluated as the ratio of the gross insurance payments to the total insurance premiums. In world practice, this figure is about $70 \%$, in the EU 15 - about 80\%, in Poland - 60\% [3], when in Ukraine it is less than 25\% (Table 1), due to the generally low level of development of the national insurance market. Among the main reasons for the low efficiency of the national insurance market insufficient solvency of insurers, low level of insured persons' loyalty, unbalanced number and structure of insurers, uneven geographical diversification of insurers, low level of infrastructure development of the insurance market and uneffective provision of insurance protection should be noted. These reasons are mainly due to the inversion way of the national insurance market's development, in order to reduce the negative impact of which, within the state regulation of the insurance market, it is necessary to strengthen the powers of state supervision bodies over the activities of insurers in the aspect of financial stability, solvency of taken risks, reinsurance, guarantees of the provision of insurance protection; sanify the market from corrupted high-risk insurance companies and those that serve tax 
optimization, or at least publicly transferring them to a quasi-insurance category by changing the conditions for their licensing so that policyholders do not refuse the insurance system after the unsuccessful experience of usage such insurers.

Considering the inversion type of development of national insurance, it should be noted that the threat of monopolization of the market and destruction of regional insurers makes a sharp decline in the number of insurers undesirable. The reduction of number of registered insurers occurs against the background of maintaining a high level of concentration on the market, in favor of this is evidenced by the growth of $\mathrm{HHI}$ in the dynamics that requires close attention from the side of the Antimonopoly Committee, since only a small number of insurers is conducting a competitive struggle for increasing their market shares. The state regulation bodies should contribute to the timely and complete reimbursement of losses to policyholders through the mechanism of sanctions of insurers on the results of checks of their complaints to the relevant committee at the National Commission for Regulation of Financial Services Markets, which will increase the level of confidence of policyholders in the insurance mechanism.

The state should support the development of the life insurance segment in order to improve the standard of living of policyholders and reduce the burden on the state pension fund, which will allow redirection of the saved state funds for the development of social sphere and industry; to encourage insurers to expand the range of insurance products through the mechanism of tax holidays for new and low-cost insurance services.

\section{References:}

1. Kyrylo, V., Kurylo, L., Zhovnirchyk, Y., Kartashov, Y., \& Sokol, S. (2017). The development of the insurance market of Ukraine amid the global trends in insurance. Management and financial innovations, 14 (1-1), 211-216.

2. Javorsjka T. V. (2013). Konkurentne reghuljuvannja strakhovogho pidpryjemnyctva Ukrajiny [Competitive regulation of insurance business of Ukraine]. Money, finance and credit. Actual problems of economy, vol. 146, no. 8, pp. 115-122.

3. The National commission exercising state regulation in the sphere of financial services markets (2018). Informatsiia pro stan i rozvytok strakhovoho rynku Ukrainy [Information on the status and development of the insurance market of Ukraine]. Retrieved from: https://www.nfp.gov.ua/ua/Informatsiia-pro-stan-i-rozvytok-strakhovoho-rynku-Ukrainy.html (in Ukrainian) 